\title{
Efektivitas Media Audio Visual Dalam Meningkatkan Hasil Belajar Siswa Pada Pembelajaran IPS Terpadu Kelas VII MTS. AI Yusufiah
}

\author{
${ }^{1}$ Nurparida, ${ }^{2}$ Erna Srirahayu \\ Institut Pendidikan Indonesia \\ Nurparida9@gmail.com, ernasrirahayu9@gmail.com
}

\begin{abstract}
In the era of information technology development, teachers have now become a demand to be able to utilize ICT in carrying out learning in a better direction. This research is motivated by the fact that most student learning outcomes have not yet reached the KKM. Audiovisual media is a vehicle for delivering information or learning messages to students, with audio-visual media it is hoped that the teacher can stimulate the cognitive development of students. The purpose of this study was to determine the effectiveness of using audiovisual media in improving student learning outcomes in social studies learning. The research method used in this study was a quasi-experimental design with a nonequivalent control group design research involving the experimental group and the control group. From the results of the posttest data analysis, it was found that the final ability average value in the experimental class was 85 and the control class was 72.5. Furthermore, the normalized gain in the experimental class is 0.72 with the high category and the control class 0.48 with a moderate category. The Ha hypothesis test is accepted, meaning that the use of audio-visual media can significantly improve student learning outcomes compared to conventional learning regarding the material of pre-literate Indonesian society in CLASS VII integrated social studies learning at MTs.Al Yusufiyah.
\end{abstract}

\section{Keywords: Audiovisual Media, Learning Outcomes, Integrated Social Studies}

Abstrak. Dalam era perkembangan teknologi informasi saat ini sudah menjadi tuntutan bagi guru untuk bisa mendayagunakannya TIK dalam melaksanakan pembelajaran kearah yang lebih baik. Penelitian ini dilatarbelakangi atas sebagian besar hasil belajar siswa belum mencapai KKM. Media audio visual merupakan wahana penyampaian informasi atau pesan pembelajaran pada peserta didik, dengan media audio visual diharapkan guru dapat merangsang perkembangan kognitif peserta didik. Tujuan penelitian ini adalah untuk mengetahui efektivitas penggunaan media audiovisual dalam meningkatkan hasil belajar siswa pada pembelajaran IPS. Metode penelitian digunakan dalam penelitian ini adalah desain dengan metode kuasi eksperimen dengan desain penelitian nonequivalent control group design melibatkan kelompok eksperimen dan kelompok control. Dari hasil analisis data posttest diperoleh nilai rata-rata kemampuan akhir pada kelas eksperimen sebesar 85 dan kelas kontrol sebesar 72.5. Selanjutnya gain ternormalisasi pada kelas ekperimen sebesar 0.72 dengan kategori tinggi dan kelas kontrol 0.48 dengan kategori sedang. Uji hipotesis Ha diterima artinya bahwa penggunaan media audio visual secara signifikan dapat lebih meningkatkan hasil belajar siswa dibandingkan dengan pembelajaran konvensional mengenai materi kehidupan masyarakat Indonesia zaman praksara pada pembelajaran IPS terpadu KELAS VII Di MTs.Al Yusufiyah

Kata Kunci : Media Audiovisual, Hasil Belajar, IPS Terpadu

\section{PENDAHULUAN}

A. Latar Belakang

Pendidikan merupakan suatu proses yang dilakukan secara sengaja dirancang guna mencerdaskan kehidupan suatu bangsa. Wujud nyata dari proses pendidikan adalah dalam bentuk proses pembelajaran. Pembelajaran adalah proses interaksi peserta didik dengan pendidik dan sumber belajar pada suatu lingkungan belajar. Tujuan pembelajaran adalah tercapainya kemampuan (kompetensi) atau keterampilan yang 
diharapkan dapat dimiliki oleh siswa setelah mereka melakukan proses pembelajaran tertentu (W Sanjaya, 2013)

Pendidikan pada dasarnya merupakan usaha sadar untuk menumbuhkembangkan potensi sumber daya manusia sebagai peserta didik dengan cara mendorong dan memfasilitasi kegiatan belajar para peserta didik. Undang-undang RI No. 2 Tahun 2003 tentang Sistem Pendidikan Nasional BAB I Pasal 1, mendefinisikan pendidikan sebagai usaha sadar dan terencana untuk mewujudkan suasana belajar dan proses belajar agar peserta didik secara aktif mengembangkan potensi dirinya untuk memiliki kekuatan spiritual keagamaan, pengendalian diri, kepribadian, kecerdasan, akhlak mulia, serta keterampilan yang diperlukan dirinya, masyarakat, bangsa dan Negara.

Proses pembelajaran dapat berjalan efektif dan efisien apabila ditunjang oleh beberapa komponen pembelajaran saling mendukung menjadi kesatuan dalam mencapai tujuan pembelajaran. Komponen pembelajaran diantaranya berupa tujuan, subjek belajar, materi pelajaran, strategi pembelajaran, media pembelajaran dan penunjang (fasilitas belajar, alat pelajaran, bahan pelajaran, dan semacamnya) (Hamdani., 2011). Keterkaitan antar komponen ikut andil terciptanya suasana belajar yang efektif untuk pencapaian hasil belajar siswa.

Dalam era perkembangan teknologi informasi saat ini sudah menjadi tuntutan bagi guru untuk bisa mendayagunakannya demi melaksanakan pembelajaran kearah yang lebih baik. Oleh karena itu, guru dituntut memiliki keterampilan menggunakan teknologi informasi dan komunikasi dalam pembelajaran. Media pembelajaran audiovisual merupakan bagian dari teknologi informasi yang menyajikan unsur media yang dapat didengar dan dilihat berupa suara dan gambar. Media audiovisual yaitu jenis media yang selain mengandung unsur suara juga mengandung unsur gambar yang dapat dilihat, seperti rekaman video, berbagai ukuran film, slide suara, dan sebagainya,(Wina. Sanjaya, 2006). Pembelajaran dengan menggunakan media audiovisual telah memberikan pengaruh yang positif dan perubahan yang signifikan (Supriatini, 2017). Selanjutnya motivasi belajar dan hasil belajar meningkat dengan penerapan media audiovisual (Bambang et al., 2015) .

Permasalahan yang ditemui dalam pelaksanaan pembelajaran IPS di MTs, Al Yusufiyah adalah sebagian besar hasil belajar siswa belum mencapai KKM. Selanjutnya penyampaian materi dijelaskan secara verbal sehingga peserta didik menjadi pasif dalam pelaksanaan pembelajaran sebatas mendengarkan penjelasan guru. Tujuan penelitian ini adalah untuk mengetahui efektivitas penggunaan media audiovisual dalam meningkatkan hasil belajar siswa pada pembelajaran IPS.

\section{B. Rumusan Masalah}

Berdasarkan uraian latar belakang masalah diatas, maka rumusan masalah dalam penelitian ini sebagai berikut ;

1. Bagaimana efektivitas penggunaan media audiovisual dalam meningkatkan hasil belajar siswa pada pembelajaran IPS terpadu?

2. Apakah terdapat perbedaan peningkatan hasil belajar siswa dengan menggunakan multimedia interaktif dan metode konvensional pada pembelajaran IPS terpadu?

\section{KAJIAN TEORITIS}

A. Pendidikan dan Pembelajaran

Pendidikan adalah usaha sadar dan terencana untuk mewujudkan suasana belajar dan proses pembelajaran agar peserta didik secara aktif mengembangkan potensi dirinya untuk memiliki kekuatan spiritual keagamaan, pengendalian diri, kepribadian, kecerdasan, akhlak mulia, serta keterampilan yang diperlukan dirinya, masyarakat, bangsa, dan negara ("Undang-Undang Republik Indonesia Nomor 20 Tahun 2003 Tentang Sistem Pendidikan Nasional," 2003) (UU No. 20 Tahun 2003). Berdasarkan uraian diatas, pendidikan merupakan usaha untuk mendidik, membina, dan mengajar kepada seseorang/individu demi pemenuhan suatu 
perilaku yang diharapkan berkaitan dengan pengetahuan, sikap, dan keterampilan.

Keberhasilan pendidikan itu sendiri dapat dicapai melalui peningkatan kualitas sumber daya manusia yang terkandung jelas dalam tujuan pendidikan nasional. Untuk mewujudkan pendidikan nasional tersebut diperlukan lembaga yang secara khusus berperan dalam mengelola pendidikan, baik formal, non formal maupun informal. Sekolah sebagai salah satu lembaga pendidikan formal mempunyai tugas dan tanggung jawab untuk mengembangkan potensi-potensi siswa secara optimal sesuai dengan bakat, minat dan kemampuan siswa.

Pembelajaran merupakan proses komunikasi antara guru dan siswa melalui bahasa verbal sebagai media utama penyampaian materi pembelajaran. Poses pembelajaran sangat tergantung pada guru sebagai sumber belajar. Dalam kondisi semacam ini, akan ada proses pembelajaran manakala ada guru; tanpa ada kehadiran guru di dalam kelas sebagai sumber belajar tidak mungkin ada proses pembelajaran. Pembelajaran sebagai proses kerjasama antara guru dan siswa dalam memanfaatkan segala potensi dan sumber yang ada baik potensi yang bersumber dari dalam diri siswa itu sendiri seperti minat, bakat dan kemampuan dasar yang dimiliki termasuk gaya belajar, maupun potensi yang ada di luar diri siswa seperti lingkungan, sarana dan sumber belajar sebagai upaya untuk mencapai tujuan belajar tertentu (Wina. Sanjaya, 2006). Selanjutnya menurut (Surya, 2003), pembelajaran adalah suatu proses usaha yang dilakukan individu untuk memperoleh suatu perubahan tingkah laku yang baru keseluruhan, sebagai hasil pengalaman individu itu sendiri dalam interaksinya dengan lingkungan.

B. Media Audiovisual

Media pembelajaran merupakan salah satu unsur dan komponen pembelajaran yang memiliki peranan penting dalam proses pembelajaran. Pemanfaatan media menjadi perhatian guru terkait peran guru sebagai fasilitator dalam pelaksanaan pembelajaran dan media berfungsi sebagai alat bantu mengajar (Suherman., 2008) .
Media pembelajaran Audiovisual adalah media instruksional modern yang sesuai dengan perkembangan zaman (kemajuan ilmu pengetahuan dan tekhnologi), meliputi media yang dapat dilihat dan didengar (Arsyad, 2007). Media audio visual merupakan wahana penyampaian informasi atau pesan pembelajaran pada peserta didik, dengan media audio visual diharapkan guru dapat merangsang perkembangan otak anak anak. Audio visual dalam media pembelajaran memiliki kelebihan dan kekurangan diantaranya dapat membantu menimbulkan pengertian dan ingatan yang kuat pada pesan yang disampaikan dan dapat dipadukan dengan unsur suara, merangsang minat dan perhatian siswa dengan gambar dan warna yang kongkrit dan aspek suara, progamnya mudah direvisi sesuai dengan kebutuhan dan penyimpanannya mudah karena ukurannya kecil, sedangkan kelemahannya antara lain memerlukan waktu yang relatif panjang untuk pembuatannya, serta memerlukan biaya yang relatif besar dan menyajikan gambar yang gerakannya terbatas (Riyana, 2007) .

\section{Hasil Belajar}

Dalam konteks pembelajaran di sekolah, belajar adalah suatu proses usaha yang dilakukan peserta didik untuk memperoleh suatu perubahan tingkah laku yang baru secara keseluruhan, sebagai hasil pengalaman peserta didik sendiri dalam interaksi dengan lingkungannya. Menurut (Hamalik, 2014) bukti bahwa seseorang telah melakukan kegiatan belajar ialah adanya perubahan tingkah laku pada orang tersebut, yang sebelumnya tidak ada atau tingkah laku tersebut masih lemah atau kurang.

Hasil belajar adalah kemampuankemampuan yang dimiliki siswa setelah siswa menerima pengalaman belajarnya (Sudjana, 2011). Selanjutnya (Sukiyasa \& Sukoco, 2013) hasil belajar merupakan dampak dari segala proses memperoleh pengetahuan, hasil dari latihan, hasil dari proses perubahan tingkah laku yang dapat diukur baik melalui tes perilaku, tes kemampuan kognitif, maupun tes psikomotorik. Berdasarkan pendapat beberapa ahli tersebut dapat disimpulkan 
bahwa hasil belajar merupakan kemampuan atau perilaku yang dimiliki peserta didik setelah melakukan aktivitas belajar sebagai hasil pengalamannya beriteraksi dengan lingkungan belajar.

D. IPS Terpadu di SMP

$$
\text { Ilmu Pengetahuan Sosial (IPS) }
$$

Terpadu merupakan mata pelajaran mengenai telaah manusia dalam hubungan sosialnya atau kemasyarakatannya. Perkembangan masyarakat terus mengalami perubahan seiring dengan kemajuan ilmu pengetahuan dan teknologi. Terakit dengan perubahan di masyarakat, pendidikan IPS Terpadu mutlak diperlukan sesuai dengan tujuan yang diharapakan. Menurut (Setiwan, 2013).

"Tujuan Pendidikan Ilmu Pengetahuan Sosial (IPS) adalah mempersiapkan warga Negara yang dapat membuat keputusan reflektif dan berpartisispasi dalam kehidupan kewarganegaan di lingkungan masyarakat, bangsa dan dunia. perubahan dan permasalahan dengan segala implikasinya yang makin pesat dapat dikembangkan menjadi materi IPS."

Berdasarkan Peraturan Menteri Pendidikan Nasional Nomor 23 tahun 2006 tentang Standar Kompetensi Lulusan untuk Satuan Pendidikan Dasar dan Menengah bahwa Standar Kompetansi IPS Terpadu adalah sebagai berikut :

1) Mengamalkan ajaran agama yang dianut sesuai dengan tahap perkembangan remja.

2) Menerapakan nilai-nilai kejujuran dan keadilan.

3) Memahami keeragaman agama, budaya, suku, ras, dan golongan sosial ekonomi.

4) Berkomunikasi dan berinteraksi secara efektif dan santun yang mencerminkan harkat dan martabatnya sebagai makhluk Tuhan.

5) Menerapkan hidup bersih, sehat, aman, dan memanfaatkan waktu luang sesuai dengan tuntunan agamanya.

6) Memnanfaatkan lingkungan sebagai makhluk ciptaan Tuhan secara bertanggung jawab.

7) Menghargai perbedaan pendapat dalam menjalankan ajaran agama.

\section{METODE PENELITIAN}

Metode penelitian digunakan dalam penelitian ini adalah desain dengan metode kuasi eksperimen. Kuasi Eksperimen digunakan untuk mengetahui efektivitas penggunaan media audiovisual dalam meningkatkan hasil belajar siswa pada mata pelajaran IPS terpadu. Desain penelitian eksperimen yang digunakan dalam penelitian ini berbentuk nonequivalent control group design dan melibatkan kelompok eksperimen dan kelompok control serta diberikan pengujian pretest dan posttest. Kelompok control menggunakan metode konvensional.

Teknik pengumpulan data dilakukan dengan memberikan test hasil belajar untuk mengukur hasil belajar siswa setelah menggunakan media audiovisual pada kelas eksperimen dan metode konvensional pada kelas control.. Populasi dan sampel dalam penelitian adalah siswa kelas VII sebanyak 36 siswa.

\section{HASIL PENELITIAN Dan PEMBAHASAN}

\section{A. Hasil Penelitian}

Dalam penelitian ini, peneliti membagi sampel siswa menjadi 2 kelompok yaitu kelompok eksperimen dan kelompok control. Sebelum diterapkan media audiovisual dan metode konvensional, kedua kelompok tersebut diberikan pretest untuk mengetahui kemampuan awal peserta didik. Setelah diterapkan media audiovisual pada kelas eksperimen dan metode konvensional pada kelas control diperoleh data hasil belajar sebagai berikut ;

Tabel 1. Nilai Pretest dan Postest Kelompok Eksperimen dan Kontrol

\begin{tabular}{|c|c|c|c|c|}
\multicolumn{1}{c|}{} & Eksperimen dan Kontrol \\
\cline { 2 - 5 } \multicolumn{1}{c|}{} & \multicolumn{2}{c|}{$\begin{array}{c}\text { Kelas } \\
\text { Eksperimen }\end{array}$} & \multicolumn{2}{c|}{ Kelas Kontrol } \\
\cline { 2 - 5 } & $\begin{array}{c}\text { Prete } \\
\mathrm{s}\end{array}$ & $\begin{array}{c}\text { Postes } \\
\mathrm{t}\end{array}$ & Pretes & Postest \\
\hline Rata-Rata & 44.72 & 85 & 45.83 & 72.5 \\
\hline Skor Maks & 60 & 90 & 60 & 80 \\
\hline Skor Min & 30 & 80 & 35 & 60 \\
\hline
\end{tabular}


Berdasarkan tabel 1 diatas, diperoleh nilai rata-rata posttest pada kelas ekperimen sebesar 85 dan kelas control sebesar 72.5 yang artinya nilai rata-rata kelas eksperimen lebih besar dibandingkan kelas control. Selanjutnya peningkatan hasil belajar pada kelompok eksperimen dan control disajikan pada tabel dibawah ini ;

\begin{tabular}{|l|l|r|r|r|r|}
\hline \multicolumn{1}{|c|}{ Tabel 2. Perbandingan Peningkatan Hasil Belajar } \\
\hline \multirow{2}{*}{ Kain } & Eksperime & $\mathrm{N}$ & Mean & $\begin{array}{c}\text { Gain.Tern } \\
\mathrm{m}\end{array}$ & $\begin{array}{c}\text { Std. } \\
\text { Deviation }\end{array}$ \\
\cline { 2 - 5 } & 18 & 40.28 & 0.72 & 8.130 \\
Kontrol & 18 & 26.67 & 0.48 & 7.290 \\
\hline
\end{tabular}

Data peningkatan hasil belajar pada kelompok eksperimen sebesar 0.72 dengan kategori tinggi dan kelompok control sebesar 0.48 dengan kategori rendah (Meltzer, D.E. (2002). The Relationship between Mathematics Preparation and Conceptual Learning Grains in Physics: A Possible "Hidden Variable" in Diagnostice Pretest Scores. American Journal Physics, 70 (12)., 2002). Hal ini menunjukan bahwa penggunaan media audiovisual lebih efektif dalam meningkatkan hasil belajar siswa dibandingkan dengan metode konvensional dalam pembelajaran IPS terpadu. Selanjutnya dilakukan uji normalitas data gain, diperoleh data sebagai berikut ;

Table 3. Uji Normalitas Data Gain

\begin{tabular}{|c|c|c|c|c|c|}
\hline & \multirow[t]{2}{*}{ Kelas } & \multicolumn{3}{|c|}{ Shapiro-Wilk } & \multirow[b]{2}{*}{$\begin{array}{c}\text { Descri } \\
\mathrm{p}\end{array}$} \\
\hline & & $\begin{array}{c}\text { Statisti } \\
\text { c }\end{array}$ & df & Sig. & \\
\hline \multirow{2}{*}{$\begin{array}{l}\text { Gai } \\
n\end{array}$} & $\begin{array}{l}\text { Eksperim } \\
\text { en }\end{array}$ & .906 & 18 & .073 & $\begin{array}{r}\text { Norma } \\
1\end{array}$ \\
\hline & Kontrol & .943 & 18 & .329 & $\begin{array}{r}\text { Norma } \\
1\end{array}$ \\
\hline
\end{tabular}

Berdasarkan hasil uji normalitas data pada tabel 3, pada kelas eksperimen diperoleh nilai propabilitasnya $0.073>0.05$ artinya bahwa sebaran data pada kelas eksperimen berdistribusi normal. Selanjutnya pada kelas kontrol diperoleh nilai propabilitasnya 0.329 . Jika dibandingkan dengan nilai signifikan 0.05 maka 0.329 > 0.05 artinya bahwa sebaran data pada kelas kontrol berdistribusi normal. Dapat disimpulkan bahwa kedua kelas tersebut berdistribusi normal. Hasil uji homogenitas pada kelas eksperimen dan kontrol diperoleh nilai propabilitasnya 0.281 . Jika dibandingkan dengan nilai signifikan 0.05 maka $0.281>0.05$ artinya bahwa data pada kedua kelas homogen. Berdasarkan uji statistik hipotesis menggunakan uji $t$ Independent Sample T-Test dengan SPSS 20 pada tabel diperoleh data bahwa nilai propabilitas adalah 0.000 . Jika di bandingkan dengan nilai signifikansi 0.000 $<0.05$ yang berarti Ho ditolak dan Ha diterima. Dapat disimpulkan bahwa penggunaan media audio visual secara signifikan dapat lebih meningkatkan hasil belajar siswa dibandingkan dengan pembelajaran konvensional mengenai materi kehidupan masyarakat Indonesia zaman praksara pada pembelajaran.

\section{Pembahasan}

1. Hasil Belajar (Pretest) Pada Kelas Eksperimen dan Kelas Kontrol

Berdasarkan uji statistik pengolahan data, diperoleh nilai rata-rata pretest peserta didik pada kelas eksperimen sebesar 44.72 dan kelas kontrol sebesar 45.83. Hal ini menunjukan bahwa nilai rata-rata pretest kelas kontrol lebih tinggi dibandingkan dengan kelas eksperimen. Nilai rata-rata pretest yang diperoleh pada kedua kelas tersebut masih jauh dari nilai KKM pembelajaran sejarah yaitu 70 . Pretestmerupakan kegiatan menguji tingkatan pengetahuan peserta didik terhadap materi yang akan disampaikan, kegiatan pretest ini dilakukan sebelum kegiatan pembelajaran. Adapun manfaat dari diadakannya preetest adalah untuk mengetahui kemampuan awal peserta didik mengenai mata pelajaran yang akan disampaikan. Dengan mengetahui kemampuan awal peserta didik ini, peneliti akan dapat mengidentifikasi seberapa besar kemajuan belajar peserta didik setelah mengikuti pembelajaran.

Pada hakikatnya pembelajaran merupakan upaya untuk membelajarkan peserta didik dengan tujuan terjadinya perubahan perilaku pada masing-masing individu. (W Sanjaya, 2013) mengemukakan bahwa pembelajaran merupakan kegiatan 
yang bertujuan membelajarkan siswa. Undang-Undang Republik Indonesia Nomor 20 Tahun 2003 tentang Sistem Pendidikan Nasional, mengemukakan bahwa pembelajaran adalah proses interaksi peserta didik dengan pendidik dan sumber belajar pada suatu lingkungan belajar. Setiap guru penting untuk memahami sistem pembelajaran, karena dengan pemahaman sistem ini, setiap guru akan memahami tentang tujuan pembelajaran atau hasil yang diharapkan, proses kegiatan pembelajaran yang harus dilakukan, pemanfaatan setiap komponen dalam proses kegiatan untuk mencapai tujuan yang ingin dicapai dan bagaimana mengetahui keberhasilan pencapaian tersebut.

\section{Hasil Belajar (Posttest) Pada Kelas} Eksperimen dan Kelas Kontrol

Pelaksanaan pembelajaran IPS Terpadu, perlakuan yang diberikan pada kelas eksperimen menggunakan media audio visual dan pada kelas kontrol dengan pembelajaran konvensional dengan menggunakan metode ceramah. Berdasarkan uji statistik pengolahan data, diperoleh nilai rata-rata posttest peserta didik pada kelas eksperimen sebesar 85 dan kelas kontrol sebesar 72.5. Hasil tersebut menunjukan bahwa nilai rata-rata pretest kelas eksperimen lebih tinggi dibandingkan dengan kelas kontrol. Posttest merupakan bentuk pertanyaan yang diberikan setelah pembelajaran atau perlakuan diberikan. Dengan kata lain posttest merupakan evaluasi akhir setelah siswa mengikuti pembelajaran. Tujuan diberikan posttest ini adalah untuk memperoleh gambaran tentang kemampuan yang dicapai setelah berakhirnya penyampaian pelajaran. Hasil posttest ini dibandingkan dengan hasil pretest yang telah dilakukan sehingga akan diketahui seberapa jauh efek atau pengaruh dari pengajaran yang telah dilakukan. Hasil belajar adalah sesuatu yang diperoleh setelah melakukan kegiatan belajar. Hasil belajar diperoleh setelah diadanya evaluasi, (Mulyasa, 2002), menyatakan bahwa" Evaluasi hasil belajar pada hakekatnya merupakan suatu kegiatan untuk mengukur perubahan perilaku yang telah terjadi". Hasil belajar ditunjukan dengan prestasi belajar yang merupakan indikator adanya perubahan tingkah laku siswa. Dari proses belajar diharapkan siswa memperoleh prestasi belajar yang baik sesuai dengan tujuan instruksional khusus yang ditetapkan sebelum proses belajar berlangsung.

Media audio-visual merupakan salah satu produk TIK, sehingga keberadaannya saat ini tidak lepas dari pengertian dan perkembangan TIK itu sendiri sebagai media yang bentuk dan penggunaannya berbasis komputerisasi (Sutopo, 2012). Menurut (DARMAWAN, 2014)

Teknologi Informasi yang mampu mengolah , mengemas, dan menampilkan, serta menyebarkan informasi pembelajaran baik secara audio, visual, audiovisual bahkan multmedia, dewasa ini telah mampu mewujudkan apa yang disebut dengan virtual learning. Konsep ini berkembang sehingga mampu mengemas setting dan realitas pembelajaran sebelumnya menjadi lebih menarik dan memberikan pengondisian secara psikologis adaptif kepada si pembelajar dimanapun mereka berada

Penerapan media audio visual lebih efektif digunakan daripada pembelajaran konvensional dengan metode ceramah dalam meningkatkan hasil belajar peserta didik pada pembelajaran IPS Terpadu. Dale (dalam (Arsyad, 2007), menyatakan bahwa media audio-visual dapat memberikan banyak manfaat di antaranya :

a. Meningkatkan rasa saling pengertian dan simpati dalam kelas;

b. Membuahkan perubahan signifikan tingkah laku siswa;

c. Menunjukkan hubungan antar mata pelajaran dan kebutuhan dan minat siswa dengan meningkatnya motivasi belajar siswa;

d. Membawa kesegaran dan variasi bagi pengalaman belajar siswa;

e. Membuat hasil belajar lebih bermakna bagi berbagai kemampuan siswa;

f. Mendorong pemanfaatan yang bermakna dari mata pelajaran dengan jalan melibatkan imajinasi dan partisipasi aktif 
yang mengakibatkan meningkatnya hasil belajar;

g. Memberi umpan balik yang diperlukan yang dapat membantu siswa menemukan seberapa banyak telah mereka pelajari;

h. Melengkapi pengalaman yang kaya dengan konsep-konsep yang bermakna dapat dikembangkan.

Berdasarkan uraian diatas berkenaan dengan proses pembelajaran dapat dikatakan, bahwa media pendidikan yang bersifat audiovisual memiliki fungsi ganda, yakni sebagai pembawa, penyalur pesan/ informasi dan sebagai unsur penunjang proses pembelajaran, sehingga memberikan manfaat yang lebih besar bagi perkembangan proses pembelajaran. Sementara perkembangan proses pembelajaran diharapkan dapat meningkatkan kualitas hasil belajar secara keseluruhan, yang pada akhirnya mampu meningkatkan prestasi belajar siswa.

3. Penerapan Media Audio Visual Secara Signifikan Dapat Meningkatkan Hasil Belajar dibandingkan Media Konvensional

Perbandingan rata-rata gain skor pada kelas eksperimen adalah 40.28 dan kelas kontrol 26.67. Hal tersebut berarti bahwa ratarata gain skor pada kelas eksperimen lebih tinggi dibandingkan dengan kelas kontrol rata-rata gain skor adalah 26.67 dengan pembelajaran konvensional. Selanjutnya gain ternormalisasi pada kelas ekperimen sebesar 0.72 dengan kategori tinggi dan kelas kontrol 0.48 dengan kategori sedang. Peningkatan hasil belajar pretest ke posttest pada kelas eksperimen dengan menggunakan media audio visual sebesar 40.28 lebih tinggi dibandingkan dengan kelas kontrol pembelajaran konvensional metode ceramah sebesar 26.67.

Berdasarkan uji statistik hipotesis menggunakan uji $t$ Independent Sample TTest dengan SPSS 20 rata-rata nilai gain diperoleh data bahwa nilai propabilitas adalah 0.000 . Jika di bandingkan dengan nilai signifikansi $0.000<0.05$ yang berarti Ho ditolak dan Ha diterima. Ha diterima artinya bahwa penggunaan media audio visual secara signifikan dapat lebih meningkatkan hasil belajar siswa dibandingkan dengan pembelajaran konvensional mengenai materi kehidupan masyarakat Indonesia zaman praksara pada pembelajaran.

\section{Kesimpulan dan Saran}

Berdasarkan hasil uji statistik analisis data pada penelitian Penerapan Media Audio Visual untuk meningkatkan hasil belajar siswa pada pembelajaran sejarah IPS Terpadu mengenai materi kehidupan masyarakat Indonesia zaman praaksara, dapat disimpulkan sebagai berikut :

1. Kemampuan awal peserta didik pada kelas kontrol lebih tinggi dibandingkan dengan kelas eksperimen. Dari hasil analisis data pretest diperoleh nilai rata-rata kemampuan awal pada kelas kontrol sebesar 45.83 dan kelas eksperimen sebesar 44.72 .

2. Kemampuan akhir peserta didik setelah pembelajaran atau perlakuan diberikan, nilai rata-rata pada kelas eksperimen lebih tinggi dibandingkan dengan kelas kontrol. Dari hasil analisis data posttest diperoleh nilai rata-rata kemampuan akhir pada kelas eksperimen sebesar 85 dan kelas kontrol sebesar 72.5. Pelaksanaan pembelajaran pada kelas eksperimen diberikan perlakuan dengan menggunakan media audio visual dan kelas kontrol dengan pembelajaran konvensional metode ceramah.

3. Peningkatan hasil belajar pada kelas eksperimen lebih tinggi dibandingkan dengan kelas kontrol. Berdasarkan hasil uji gain skor diperoleh nilai rata-rata kelas ekperimen sebesar 40.28 dan kelas kontrol 26.67. Selanjutnya gain ternormalisasi pada kelas ekperimen sebesar 0.72 dengan kategori tinggi dan kelas kontrol 0.48 dengan kategori sedang. Uji hipotesis $\mathrm{Ha}$ diterima artinya bahwa penggunaan media audio visual secara signifikan dapat lebih meningkatkan hasil belajar siswa dibandingkan dengan pembelajaran konvensional mengenai materi kehidupan masyarakat Indonesia zaman praksara pada pembelajaran. 


\section{DAFTAR PUSTAKA}

Arsyad, A. (2007). Media Pembelajaran. Jakarta: Raja Grafindo Persada.

Bambang, L., Husain, S. N., \& Rede, A. (2015). Penerapan Pembelajaran Media Audio-Visual Untuk Meningkatkan Motivasi Dan Hasil Belajar Pada Mata Pelajaran Biologi Di Kelas VIII A SMP GKST Imanuel Palu. Jurnal Sains Dan Teknologi Tadulako, 4(1), 23-28.

DARMAWAN, D. (2014). INOVASI PENDIDIKAN. Rosda Karya, 322. ROSDA

Hamalik, O. (2014). Kurikulum dan Pembelajaran. Jakarta: Bumi Aksara.

Hamdani. (2011). Strategi Belajar Mengajar. Bandung: CV. Pustaka Setia.

Meltzer, D.E. (2002). The Relationship between Mathematics Preparation and Conceptual Learning Grains in Physics: A Possible "Hidden Variable" in Diagnostice Pretest Scores. American Journal Physics, 70 (12). (2002). 70(12), 2002.

Mulyasa, E. (2002). Manajemen Berbasis Sekolah. In bandung: Rosdakarya.

Riyana, C. (2007). Media Pembelajaran. Bandung: CV Wacana Prima.

Sanjaya, W. (2013). Penelitian Pendidikan Jenis, Metode, dan Prosedur. Jakarta: Kencana Prenada Media Grup.

Sanjaya, Wina. (2006). S trategi Pembelajaran: Berorientasi Standar Proses Pendidikan . Jakarta: Kencana Prenada Media., 2006.

Setiwan, D. (2013). Reorientasi Tujuan Utama Pendidikan IPS Dalam Perspektif Global. Jupiis, 5, 58-72.

Sudjana, N. dan R. (2011). Media Pengajaran. Bandung: Bandung: Sinar Baru Algesindo.

Suherman. (2008). Pengembangan Media Pembelajaran ABK . (Makalah Pada Diklat Profesi Guru). Bandung., 2008.

Sukiyasa, K., \& Sukoco, S. (2013). Pengaruh media animasi terhadap hasil belajar

Jurnal Ilmu Sosial dan Pendidikan dan motivasi belajar siswa materi sistem kelistrikan otomotif. Jurnal Pendidikan Vokasi, 3(1), 126-137. https://doi.org/10.21831/jpv.v3i1.158 8

Supriatini, S. (2017). Penerapan Media Audio Visual Dalam Meningkatkan Keterampilan Menulis Puisi Siswa Kelas Viii Smp Negeri 13 Palembang. Jurnal Bindo Sastra, 1(1), 45. https://doi.org/10.32502/jbs.v1i1.667

Surya, M. (2003). Psikologi Pembelajaran dan Pengajaran . Bandung: Yayasan Bhakti Winaya., 2003.

Sutopo, A. H. (2012). Teknologi Informasi dan Komunikasi dalam Pendidikan. Yogyakarta: Graha Ilmu., 2012.

Undang-Undang Republik Indonesia Nomor 20 Tahun 2003 Tentang Sistem Pendidikan Nasional. (2003). Zitteliana, 19(8), 159-170. 